
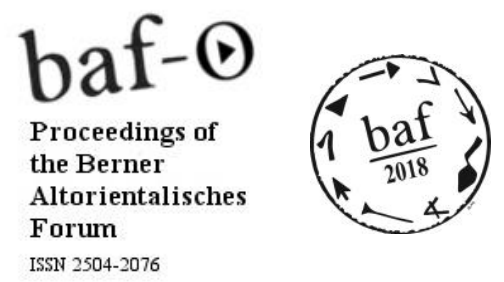
Abstract
Néhémie Strupler
Université de Strasbourg/
Institut Français d'Études Anatoliennes
DOI: http://dx.doi.org/10.22012/baf.2018.14

\title{
Sacked and Cursed? New data on the transition from the city-state to the Hittite capital Hattuša
}

During the first centuries of the 2nd millennium Assyrian and Anatolian merchants took part in a large-scale commercial exchanges between Aššur and central Anatolia. Most of the epigraphic finds come from the 19th century BC, and the 18th is less known. We don't know how the commercial exchanges came to an end and until the establishment of the administration at the Hittite capital Hattuša, there is a hiatus in the epigraphical records for more than a century. The latter so-called Anitta text recounts events that should have taken place during these "dark ages" and relates the sack and curse of Hattuša by Anitta, king of Kuššara.

Archaeological fieldwork at Boğazköy/Hattuša in 2013 provided well stratified material from these dark ages and require a reconsideration of the nature of the emergence of the Hittite State. This talk will present preliminary results of the ongoing research in a broader context to better understand the transition from a city-state to the Hittite capital and shed some light on these dark ages. 